\title{
Eksistensi Civic Engagement dan Elite Integration dalam Konflik Sunni-Syiah di Sampang
}

\author{
Affaf Mujahidah \\ Center for Marginalized Society Studies (CMARs), Surabaya \\ aff.kyo7@gmail.com
}

\begin{abstract}
The conflict between Sunni and Shia groups in Sampang did not take place at once but rather through certain periods of time when each conflict had triggered another conflict. In each period, either the government and religious elite has a pivotal role to evaluate, charge or discharge, civic engagement and elite integration in the conflict process. This article is aimed to analyze the violence against Shia group in three periods of time: pre-conflict, midi-conflict, and post-conflict. The first period started after Kiai Makmun had passed away. The second was when the violence occurred in December 29th 2011 and August 26 th 2012. And the third occurred after the violence had taken place. Although the conflict has run for several years, it has not shown the end. In order to explain this problem, this article bases on two hypotheses: first, the conflict has been caused by the absence of civic engagement. And second, which was caused the conflict continuation, has been caused by elite integration, which has never occurred on the society. This article concludes two things: first, civic engagement that can find only intra-communal engagement (intra-community engagement). And second, elite integration cannot be created because Shia's Kiai had not been legitimized by Sunni's Kiai.
\end{abstract}

Keywords: Civic Engagement, Elite Integration, Shia Sampang Conflict. 


\section{Pendahuluan}

Kekerasan terhadap kelompok Syiah di Sampang tidak terjadi secara tiba-tiba. Namun, terdapat beberapa periodisasi konflik dimana masing-masing periode memiliki proses konflik yang terjadi. Periode prakonflik merujuk pada proses benih-benih konflik mulai muncul; periode konflik dimana konflik kekerasan terjadi dan periode pasca-konflik dimana proses intervensi konflik dilakukan.

Pada masing-masing periode baik, pemerintah maupun elit agama (yang kemudian terwujud pada organisasi agama) memiliki peran yang signifikan. Kelompok- kelompok tersebut yang menjadi penentu ada tidaknya civic engagement (keterlibatan sipil) dan elite integration (integrasi elit) dalam proses konflik yang terjadi di Sampang. Poin penting yang akan dibahas adalah menelaah problematika yang terjadi dalam proses konflik tersebut serta keberadaan civic engagement dan elite integration pada masyarakat yang berkonflik.

Berdasarkan fakta-fakta yang ditemukan, penyebab belum selesainya konflik yang terjadi berdasarkan teori civic engagement dan elite integration. Hal yang diuji dalam artikel ini adalah sejauh mana teori tersebut dapat menjelaskan proses konflik yang ada sehingga dapat diketahui faktor-faktor yang menyebabkan belum tuntasnya konflik tersebut. Dari hasil kajian yang ada, ada dua faktor penting yang menyebabkan konflik tetap berlangsung dan belum dapat diselesaikan, yakni tidak terwujudnya civic engagement (partisipasi publik), dan integrasi elit (elite integration) antar pihak yang terlibat kekerasan.

Civic engagement dapat dimaknai sebagai partisipasi publik. Definisi yang dimaksud adalah adanya kerjasama dalam masyarakat melalui hubungan secara keseharian maupun formal. Civic engagement yang bersifat keseharian adalah hubungan antartetangga yang terbina sebagai akibat interaksi harian. Sedangkan yang berbentuk formal adalah civic engagement yang terjadi dalam suatu organisasi yang resmi. Menurut polanya, civic engagement dapat terbagi menjadi intra-communal engagement yang terjadi 
antar anggota dalam satu kelompok dan inter-communal engagement yang terjadi antar anggota dalam kelompok yang berbeda. ${ }^{1}$

Elite integration secara harfiah berarti integrasi elit. Secara istilah sebagai suatu kesepakatan yang terjadi pada elit dari berbagai kelompok. Elite integration dapat terjadi jika, antar elit memiliki konsensus dan kesepahaman tunggal yang sama. ${ }^{2}$ Kondisi tersebut sebagaimana konflik yang terjadi di Madura disebabkan adanya patron-client yang tinggi pada masyarakat tersebut.

\section{Penjelasan Istilah}

\section{Civic Engagement}

Teori Putnam tentang Social Capital merupakan awal dari terbentuknya teori mengenai partisipasi masyarakat. Social capital berkenaan dengan ciri-ciri organisasi sosial, seperti: jaringan (network), norma-norma dan kepercayaan yang memfasilitasi terbentuknya koordinasi dan kepercayaan demi tercapainya keuntungan bersama. ${ }^{3}$ Social capital membawa pengaruh luas dan penting yang memungkinkan penyelesaian masalah secara mudah dan peningkatan keuntungan pribadi melalui kerja sama. Putnam menggunakan teori ini untuk memberikan penjelasan mengenai berhasil atau tidaknya suatu pemerintahan regional. Terdapat perbedaan besar antara daerah yang memiliki pola social capital kuat dan yang tidak. Di wilayah Italia utara, masyarakatnya secara aktif berpartisipasi dalam kegiatan masyarakat. Kebijakan yang diambil pemerintahannya memiliki pola yang variatif, efisien dan efektif dalam penerapannya. Berbanding terbalik dengan wilayah Italia selatan yang

\footnotetext{
${ }^{1}$ Ashutosh Varshney, Ethnic Conflict and Civic Life: Hindus and Muslims in India (Yale: Yale University Press, 2002), 3.

2 Muhammad Zulfan Tadjoeddin, "Civil Society Engagement and Communal Violence: Reflections of Various Hypotheses in the Context of Indonesia", dalam Politics Administration and Change, No. 42 (Desember 2004), 2.

${ }^{3}$ Robert D. Putnam, Making Democracy Work: Civic Tradition in Modern Italy (New Jersey: Princeton University Press, 1992) 167.
} 
tidak didukung oleh kuatnya partisipasi masyarakat, pemerintahan mereka cenderung korup dan tidak efektif.

Civic engagement merupakan salah satu unsur terpenting dalam social capital, karena masyarakat sendiri merupakan individu yang terikat dengan individu lainnya. Melalui keterikatan akhirnya dapat merumuskan wujud saling pengertian sehingga, masyarakat dapat mengatur kebijakan mereka sendiri.

Dalam bukunya, Ethnic Conflict and Civic Life: Hindus and Muslim in India (2002), Varshney mengembangkan konsep civic engagement. Civic engagement secara harfiah adalah partisipasi publik yakni; adanya kerjasama dalam masyarakat melalui hubungan secara keseharian maupun formal. Civic engagement dibagi menjadi dua yaitu: Pertama, lebih bersifat struktural. Kedua, bersifat keseharian. ${ }^{5}$ Yang termasuk dalam civic engagement yang bersifat resmi adalah: perkumpulan bisnis, organisasiorganisasi profesional, klub film, klub olahraga, persatuan dagang, partai politik. Sedangkan, aktivitas rutin masyarakat seperti: saling berkunjung, makan bersama, partisipasi dalam sebuah festival dan mengizinkan anakanak mereka bermain bersama adalah contoh dari bentuk keseharian civic engagement.

Teori yang diajukan Varshney berdasarkan pada konflik antara komunitas Hindu dan Muslim di India. Konflik ini diklasifikasikan sebagai konflik etnis. Karena, berkaitan dengan identitas suatu kelompok (termasuk ras, bahasa, agama, suku, atau kasta) dapat disebut sebagai konflik etnis. Contoh-contoh lain dari konflik etnis sendiri adalah: 1) konflik Protestan-Katolik di Irlandia Utara, dan Hindu-Muslim di India, 2) konflik warna kulit hitam-putih di Amerika Serikat dan Afrika Selatan, 3) konflik Tamil-Sinhala di Sri Lanka serta 4) masalah Syiah dan Sunni di Pakistan. Semua konflik tersebut didasarkan pada permasalahan agama, ras, bahasa, dan sekte. ${ }^{6}$

\footnotetext{
${ }^{4}$ Ibid., 182.

5 Varshney, Ethnic Conflict and Civic Life, 3.

${ }^{6}$ Donald Horowitz, Ethnic Groups in Conflict (Berkeley: University of California Press, 1985); Varshney, Ethnic Conflict and Civic Life, 4-5.
} 
Varshney menunjukkan adanya hubungan yang kuat antara struktur komunitas plural dan masyarakat sipil dengan ada atau tidaknya kekerasan komunal. Dua bentuk civic engagement, inter-komunitas dan antar-komunitas memerankan peran berbeda dalam konflik etnis. Jika civic engagement hanya terwujud dalam suatu komunitas, sementara hubungan antar-kelompok lemah atau tidak ada sama sekali, maka kemungkinan besar akan terjadi kekerasan komunal. Begitu pula sebaliknya, civic engagement dalam tataran antar-kelompok akan mewujudkan perdamaian (lihat gambar 1).

Gambar 1

Kekerasan dan Perdamaian Kelompok

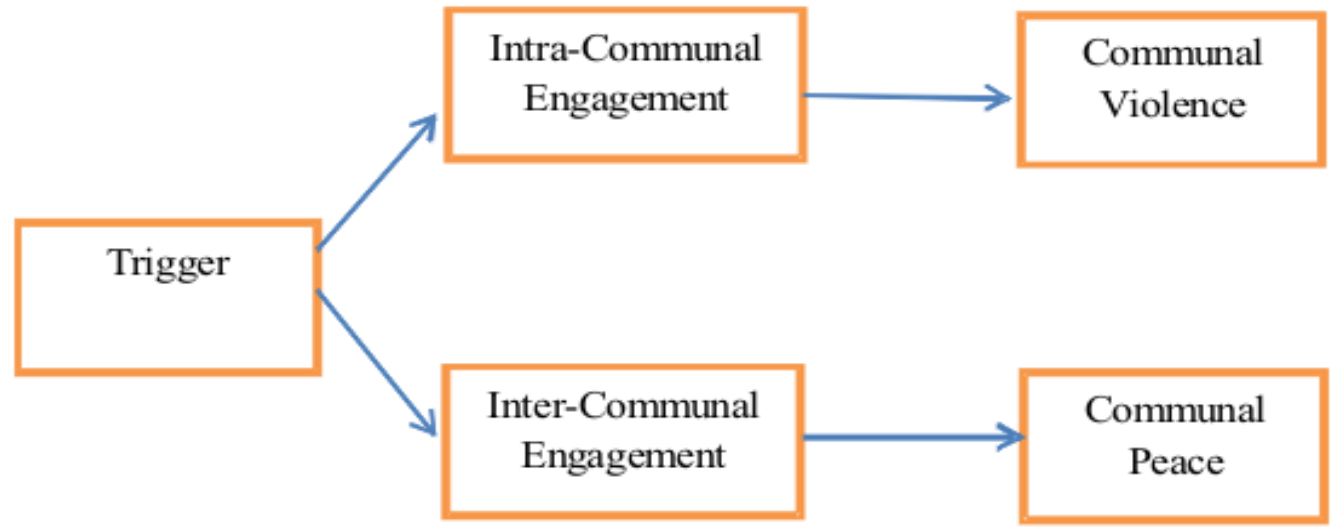

Dalam konteks konflik antara komunitas Sunni dan Syiah, tidak terdapat unsur yang mendukung dalam penciptaan civic engagement dalam masyarakat Madura yang sedang berkonflik. Hal ini dapat dilihat dari tidak adanya institusi sosial atau gerakan yang dapat menandingi gerakan anti-Syiah agar, tidak melakukan kekerasan. Dengan kata lain, komunitas anti-Syiah adalah mayoritas dan mendominasi berbagai segi dalam masyarakat. Hal lain yang menyebabkan civic engagement sulit diwujudkan pada masyarakat Madura adalah adanya patron-client antara pemuka agama dan tokoh masyarakat dengan masyarakat. Masyarakat Madura akan patuh dan mengikuti pemimpin mereka. Hal ini bahkan tercantum dalam salah satu prinsip budaya Madura itu sendiri (buppa', babbu, guru, rato 
[bapak, ibu, guru, pemimpin]). ${ }^{7}$ Prinsip inilah yang mengatur kewajiban ketaatan bagi orang Madura.

Varshney sendiri mendefinisikan civic engagement tersebut harus memenuhi tiga klasifikasi, di antaranya: Pertama, berada di antara keluarga (masyarakat) dan negara yang memungkinkan masyarakat melakukan semua jenis kegiatan publik dan bebas dari negara. Kedua, mampu membuat hubungan antara para individu dengan keluarga (masyarakat) menjadi mungkin diwujudkan. Ketiga, harus mandiri dan tidak tergantung kepada Negara. ${ }^{8}$ Civic engagement tidak bersifat politik dan tidak bersifat kenegaraan. Fungsinya bersifat non-kenegaraan, civic engagement dapat mewadahi kegiatan yang bersifat sosial dan politis. Jika ditelaah dari syarat pertama lembaga masyarakat, persatuan dagang dapat dimasukkan sebagai lembaga masyarakat namun, perkumpulan antar tetangga tidak. Berdasarkan syarat kedua, klub filatelis (pengumpul prangko) dan perkumpulan orang tua-guru termasuk lembaga namun, perkumpulan gereja hitam maupun Yahudi tidak.

Jika dibandingkan dengan pengelompokan kota oleh Varshney, konflik yang terjadi di Sampang dapat dianalogikan dengan kelompok kedua, yakni: Hyderabad dan Lucknow. Seperti kedua kota tersebut, komunitas yang berkonflik di Sampang memiliki peraturan-peraturan yang diatur oleh komunitas Muslim terdahulu yang hingga saat ini masih dipertahankan. Contoh: pelaksanaan Maulid Nabi yang dilaksanakan di masing-masing rumah penduduk. ${ }^{9}$ Meskipun ada satu komunitas yang berusaha memperbaharui tradisi ini namun, peraturan ini masih dijalankan oleh sebagian besar penduduk. Hubungan patron-client pun masih sangat kental di Sampang, apalagi daerah yang berkonflik terletak dalam kondisi yang masih pedalaman. Falsafah Madura buppha' bapphu, guru, ratoh sangat dipegang dalam kehidupan sehingga posisi kiai atau

7 Kepada figur-figur utama itulah kepatuhan hirarkis orang-orang Madura menampakkan wujudnya dalam kehidupan sosial budaya mereka. A. Latief Wiyata, Carok: Konflik. Kekerasan dan Harga Diri Orang Madura (Yogyakarta: LKiS, 2006) 49.

8 Ashutosh Varshney, "Ethnic Conflict and Civil Society", dalam Journal World Politic, Vol. 53 No. 3 (April 2001), 366.

${ }_{9}^{9}$ Iklil al-Milal, Wawancara, 10 Mei 2014. 
tokoh agama dijunjung tinggi. ${ }^{10}$ Di daerah yang berkonflik tersebut juga memiliki kesamaan kultural karena memang pada prinsipnya para penduduk berasal dari satu etnis (Madura) dan berada dalam satu wilayah sehingga kultur yang berkembang pun sama.

\section{Elite Integration}

Respons kritis terhadap Varshney diajukan oleh Muhammad Zulfan Tadjoeddin. Berbeda dengan Varshney yang menonjolkan peran masyarakat dalam pencegahan dan penyelesaian konflik, Tadjoeddin berpendapat bahwa baik masyarakat maupun negara memiliki potensi yang sama. Potensi tersebut termasuk potensi untuk menyelesaikan atau pun memperbesar konflik. ${ }^{11}$

Meskipun begitu, Tadjoeddin tetap menggunakan teori intercommunal civic engagement sebagai salah satu langkah untuk mencegah dan menyelesaikan konflik dalam konteks kasus di Indonesia. Di samping itu, Tadjoeddin juga mengemukakan pendapat lain yang dinilai sesuai dengan yang terjadi di Indonesia. Pendapat tersebut adalah elite integration (integrasi elit).

Integrasi elit merupakan teori yang sesuai diterapkan di Indonesia yang memiliki budaya patron-client yang kuat. Secara harfiah, teori ini berarti integrasielit. Secara istilah sebagai suatu kesepakatan yang terjadi pada elit dari berbagai kelompok. Pemikiran ini harus dipahami dalam dua perspektif, elite coordination (koordinasi elit) dan consociational (pembagian kekuasaan). Dalam beberapa konteks, elite coordination berhubungan erat dengan self-policing. Sedangkan consociational dapat dimaknai sebagai konsensus, pembagian kekuasaan dan kesepakatan antar elit agama. ${ }^{12}$

Integrasi elit diharapkan dapat menjembatani perpecahan antar dua atau lebih komunitas. Karena itu, integrasi massa antara kelompok tersebut sulit dibangun. Konsep ini mengharapkan peran signifikan dari

\footnotetext{
${ }^{10}$ Ahmad Zainul Hamdi, "Klaim Religious Authority dalam Konflik Sunni-Syi'I Sampang Madura", dalam ISLAMICA, Vol. 6, No.2, Maret 2012, 219-220.

11 Mohammad Zulfan Tadjoeddin, "Civil Society Engagement and Communal Violence", 2.

12 Ibid., 8.
} 
tokoh kedua kelompok untuk membangun pengertian bersama dan keyakinan tunggal diantara pihak yang bertikai. ${ }^{13}$ Sehingga, hubungan yang dibangun adalah hubungan vertikal antara tokoh (elit) dan pengikut setelah itu, dibangun pula hubungan horizontal antara kedua belah pihak.

Terwujudnya integrasi elit itu sendiri didasarkan pada dua syarat. Pertama adalah ketika nilai yang disepakati (konsensus) ada di antara para elit dan didukung oleh kerjasama serta keyakinan tunggal antar kelompok yang berbeda. Kedua, adanya jaringan interaksi personal baik secara inklusif maupun eksklusif antar kelompok dalam satu komunitas. ${ }^{14}$ Tadjoeddin mengutip pernyataan Putnam bahwa civic engagement yang bersifat keseharian akan melahirkan konsensus atau norma dan jaringan (network) yang akan bertransformasi menjadi kepercayaan bersama (mutual trust)..$^{15}$

Integrasi elit harus dipahami secara keseluruhan (subtantive engagement), bukan hanya sekedar istilah secara fisik saja. Terkadang, hal ini terlihat jika hubungan antar elit hanya keakraban yang informal saja tanpa mencerminkan apa yang terjadi di level bawah (grassroots) sendiri. Meski para elit terlihat berhubungan secara damai, namun perselisihan di akar rumput masih berlangsung. ${ }^{16}$

Tadjoeddin merekomendasikan untuk menggunakan kombinasi kebijakan-kebijakan tersebut dalam mengatasi konflik di Indonesia. Pendapat ini dikemukakan mengingat kondisi masyarakat Indonesia itu sendiri. Kondisi tersebut adalah: (1) perbedaan masyarakat yang tinggi; (2) struktur masyarakat yang masih paternalistis; ${ }^{17}$ dan (3) kekerasan biasanya dipicu oleh konflik antar-individu.

Jika dianalisis menurut pemikiran Zulfan Tadjoeddin, penyebab konflik belum dapat diselesaikan terletak pada tidak adanya integrasi elit oleh kedua belah pihak. Tadjoeddin menyakini bahwa, integrasi elit dapat mencegah terjadinya kekerasan. Integrasi elit dapat diwujudkan jika: 1)

\footnotetext{
13 Ibid., 7 .

14 Ibid., 8.

15 Ibid.

${ }^{16}$ Ibid., 10

${ }^{17}$ Ibid., 9.
} 
terdapat nilai yang disepakati ada di antara para elit dan didukung oleh masyarakatnya dan terdapat kebenaran tunggal di antara kelompok yang berbeda. 2) terdapat jaringan interaksi personal baik secara inklusif maupun eksklusif dalam kelompok yang berbeda dalam suatu komunitas. ${ }^{18}$

Dalam kasus yang terjadi, kedua hal tersebut tidak dapat diwujudkan. Bentuk civic engagement yang ideal tidak bisa terwujud karena tidak ada institusi atau gerakan yang mampu melindungi komunitas Syiah. Tidak ada kelembagaan masyarakat yang cukup kuat yang dapat mengimbangi organisasi-organisasi bentukan elit agama di wilayah tersebut. Hal ini juga berkaitan dengan elit dari kedua belah pihak yang juga tidak mampu mewujudkan perdamaian antarkelompok yang bertikai. Berdasarkan hal tersebut, penelitian ini dimaksudkan untuk menguji apakah asumsi mengenai tidak terwujudnya civic engagement dan elit integration adalah faktor yang menyebabkan tidak terwujudnya penyelesaian antara kedua belah pihak yang bertikai.

\section{Proses Konflik}

1. Periode Prakonflik

Bibit-bibit konflik telah dimulai sejak tahun 2004 yang diawali dengan ketegangan antara Kiai Makmun dan Kiai Karrar. Beberapa tokoh agama merasa resah terhadap kegiatan belajar mengajar ilmu agama (madrasa dînîyah) yang dilakukan di kediaman Tajul Muluk, namun belum berani melakukan konfrontasi secara terang-terangan. Penolakan terang-terangan baru terjadi setelah meninggalnya Kiai Makmun pada Juni tahun 2004. Tahun 2006 menjadi awal kelompok Syiah mengalami berbagai intimidasi.

Pada tanggal 24 Februari 2006, Tajul Muluk dihadirkan pada pertemuan di rumah almarhum H. Sya'bi guna mengklarifikasi ajaran yang disebarkannya. Pertemuan ini dihadiri oleh bupati Sampang saat itu (H. Fadhillah Budiono) dan kepala Kankemenag (Kantor Kementerian Agama) Kabupaten Sampang (Imron Rosyidi). Karena ketidakhadiran

18 Ibid., 7-8. 
Tajul maka, dua hari setelahnya yaitu: tanggal 26 Februari 2006, diadakan lagi pertemuan di masjid Landeko', Karang Gayam yang juga merupakan tempat tinggal dari kakek Tajul (Kiai Ahmad). Agenda pertemuan ini adalah klarifikasi yang sebelumnya tertunda, yaitu pengklasifikasian aliran yang dibawa Tajul Muluk. Semua yang hadir di pertemuan sebelumnya ikut hadir dalam pertemuan kali ini, ditambah dengan ketua MUI Sampang saat itu (Mubassyir) dan Kapolsek Omben waktu itu.Secara resmi, pertemuan ini dinamakan Forum Musyawarah Ulama (FMU) Sampang-Pamekasan. Pada pertemuan ini Tajul mengemukakan pendapat bahwa Syiah (ajaran yang dianutnya) bukan ajaran sesat seperti yang dituduhkan oleh para ulama, sedangkan FMU mengeluarkan keputusan bahwa aliran yang dianut Tajul bertolak belakang dengan ajaran yang dianut oleh para elit agama, dan atas penolakan yang dilakukan oleh Tajul Muluk, maka FMU menyerahkan perkara ini kepada pihak yang berwajib.

Pada 26 Oktober 2009, PC NU Sampang mengadakan pertemuan bersama ulama dan Muspika Kecamatan Omben untuk membahas keberadaan aktivitas dakwah Tajul Muluk dan jamaah Syiah di wilayah Kecamatan Omben. Dalam pertemuan ini Tajul Muluk diberikan sejumlah 32 pertanyaan tentang ajaran-ajaran Syiah yang dianggap sesat. Dalam keadaan terpojok, akhirnya Tajul Muluk menandatangani surat pernyataan yang berisi bahwa dirinya bersedia untuk menghentikan aktivitas mengajarkan ajaran Syiah di Sampang. Berdasarkan hasil pertemuan tersebut, PAKEM Kabupaten Sampang, MUI Kabupaten Sampang, Kankemenag Kabupaten Sampang, PC NU Sampang, Ulama dan tokoh masyarakat mengeluarkan surat bersama yang isinya Tajul tidak diperbolehkan lagi menyebarkan ajaran Syiah di Sampang dan segala gerak-gerik Tajul akan dimonitor oleh PAKEM, MUI, dan NU Sampang. Jika Tajul melakukan pelanggaran terhadap kesepakatan ini, ia akan dikenai sanksi hukum.

Sehari setelah pembubaran maulid nabi di kediaman Tajul Muluk tanggal 4 April 2011 diadakan sebuah pertemuan tertutup yang diinisiasi oleh Polda Jawa Timur di pendopo kabupaten. Pada acara ini hadir KH Muhaimin Abdul Bari(Ketua PCNU Sampang), K.H. Syafiduddin Abdul Wahid (Rais Syuriah NU), KH Bukhori Maksum (Ketua MUI 
Sampang), KH Zubaidi Muhammad, KH Ghazali Muhammad, dan beberapa ulama lainnya. Pada pertemuan ini pihak Tajul Muluk didesak untuk menerima beberapa opsi yang ditawarkan oleh MUI PCNU dan BASSRA. Opsi-opsi yang dikemukakan adalah agar Tajul menghentikan semua aktivitas Syiah atau bersedia keluar dari Sampang tanpa ganti rugi. Jika kedua opsi tersebut tidak dipenuhi maka, semua penganut Syiah harus mati. ${ }^{19}$

Tanggal 11 April 2011 tokoh agama Sampang melakukan pertemuan di Pondok Pesantren Darul Ulum di Desa Gersempal, Kecamatan Omben. Pertemuan ini diikuti oleh sejumlah pejabat Kabupaten Sampang dan Kapolres Sampang. Pada pertemuan tersebut berhasil didapatkan keputusan bahwa Polres menyatakan dukungan atas rekomendasi ulama Sampang agar relokasi Tajul segera dilaksanakan. Selain itu, Polres juga menyerukan agar melakukan pendekatan persuasif terhadap pengikut Syiah. ${ }^{20}$ Tanggal 28 Mei 2011, MUI se-Madura secara resmi mengeluarkan sikap, yang isinya menyatakan bahwa Syiah yang dianut oleh Tajul merupakan ajaran sesat dan meminta pemerintah segera melaksanakan rencana relokasi Tajul. ${ }^{21}$

Pada 30 Mei 2011 diadakan pertemuan antara Asisten I Pemprov Jatim, Bakesbangpol Prop. Jatim, Dinas Sosial Prop. Jatim, Ketua MUI Jawa Timur, Sekda Kab. Sampang, Bakesbangpol Sampang, Dandim 0828 Sampang, Kasat Intel Polres Sampang, Muspika Omben, Ketua MUI Sampang, Kakankemenag Kabupaten Sampang. Hasil dari pertemuan ini adalah kesediaan pemerintah menjadi fasilitator anggaran relokasi Tajul, dan melakukan pendekatan kepada Tajul agar bersedia menandatangani berita acara relokasi tersebut.

2. Periode Konflik

Periode konflik ditandai dengan adanya konfrontasi terangterangan dari pihak anti-Syiah terhadap Syiah. Konfrontasi ini berupa penyerangan hingga pembakaran kediaman warga Syiah. Dua peristiwa

\footnotetext{
${ }^{19}$ Hamdi, "Klaim Religious Authority, 221-222; KontraS, Laporan Investigasi dan Pemantauan Kasus Syi'ah Sampang (Surabaya: Kontras, 2012), 7.

${ }^{20}$ KontraS, Laporan Investigasi dan Pemantauan Kasus Syi'ah Sampang, 7-8.

${ }^{21}$ Ibid.
} 
penting yang termasuk dalam konflik ini adalah penyerangan pada 29 Desember 2011 dan penyerangan di tanggal 26 Agustus 2012.

Tanggal 29 Desember 2011 terjadi penyerangan, pembakaran rumah warga Syiah, serta pengusiran warga. Peristiwa ini mengakibatkan empat rumah penganut Syiah terbakar, yakni: 4 rumah tersebut adalah 2 milik Iklil al-Milal, 1 milik Hani (adik Iklil, Tajul, dan Rois), dan 1 milik Tajul Muluk. Selain mengakibatkan empat rumah terbakar, penyerangan ini juga mengakibatkan penganut Syiah yang berjumlah sekitar 300 orang mengungsi di GOR Tennis Indoor Sampang. Pemicu terjadinya penyerangan ini dikarenakan anggapan bahwa Tajul melanggar perjanjian yang telah ia sepakati bersama Pemerintah Sampang dan Pemerintah Provinsi Jawa Timur untuk bersedia direlokasi dan tidak kembali semasa masa pengasingan. ${ }^{22}$

Pascakekerasan yang terjadi pada tanggal 29 Desember 2011, MUI Kabupaten Sampang mengeluarkan fatwa yang menyatakan bahwa ajaran yang disebarkan oleh Tajul adalah ajaran sesat. Fatwa sesat ini dikeluarkan pada tanggal 1 Januari 2012. Sehari setelahnya, pada 2 Januari 2012, PC NU Kabupaten Sampang mengeluarkan surat pernyataan yang mendukung keputusan MUI Kabupaten Sampang. ${ }^{23}$

Tanggal 3 Januari 2012, BASSRA meminta MUI Pusat dan MUI Jawa Timur mengeluarkan fatwa bahwa Syiah adalah sesat. Selain itu, BASSRA juga meminta Pemkab Sampang melarang ajaran Syiah berkembang di Madura. ${ }^{24}$ Permintaan ini ditanggapi dengan adanya pengeluaran keputusan sesat pada tanggal 21 Januari 2012. MUI Provinsi Jawa Timur juga mengeluarkan fatwa sesat ajaran Syiah. Fatwa sesat ini tertulis dalam Keputusan Fatwa Majelis Ulama Indonesia (MUI) Provinsi

\footnotetext{
${ }^{22}$ Iklil Milal, Wawancara 10 Mei 2014; Tajul Muluk, Wawancara, 10 Mei 2014; Lihat juga KontraS, Laporan Investigasi dan Pemantauan Kasus Syi'ab Sampang, 8; dan A.H Semendawai, dkk., Laporan Tim Temuan dan Rekomendasi (TTR) Tentang Penyerangan Terbadap Penganut Syiah di Madura, 3.

23 Laporan Tim Temuan dan Rekomendasi (TTR) tentang Penyerangan Terhadap Penganut Syiah di Sampang, 3

${ }^{24}$ Semendawai, dkk., Laporan Tim Temuan dan Rekomendasi (TTR) Tentang Penyerangan Terhadap Penganut Syiah di Madura, 3.
} 
Jawa Timur No. Kep-01/SKF-MUI/JTM/I/2012 Tentang Kesesatan Ajaran Syiah. ${ }^{25}$

Warga Syiah yang berada di GOR Tennis Indoor Kabupaten Sampang baru dapat dipulangkan pada tanggal 12 Januari 2012. Kepulangan mereka didasari oleh instruksi dari sejumlah pejabat dan pegawai Pemerintah Kabupaten Sampang. Instruksi ini dikeluarkan karena situasi di Nangkernang telah dianggap aman dan kondusif. Namun sayangnya, kepulangan warga ini tidak boleh disertai dengan pemimpin Syiah (Tajul Muluk, Iklil, Saiful, dan Ali). ${ }^{26}$

Tanggal 16 Maret 2012, Tajul dijatuhi hukuman selama dua tahun penjara. Hukuman ini diberikan atas dakwaan penistaan agama. Penjatuhan vonis ini sesuai dengan surat No.S.Pgl/626/III/2012/Ditreskrimum, tanggal 16 Maret 2012 berdasarkan LP no:LP/03/I/2012/Polres, tanggal3 Januari 2012 dan surat perintah penyidikan no: Sp.Sidik/47/I/2012/Ditreskrimum tanggal 27 Januari 2012. ${ }^{27}$

Hukuman yang dijatuhkan kepada Tajul mencapai final pada tanggal 12 Juli 2012. Keputusan ini diambil Pengadilan Negeri Sampang dalam keputusan No.69/Pid.b/2012/PN.Spg yang berisi Tajul Muluk dijatuhi hukum penjara 2 tahun karena melanggar KUHP 156 tentang penodaan agama. Penodaan agama yang dilakukan oleh Tajul dalam keputusan ini dikarenakan Tajul menganggap bahwa isi Alquran tidak asli. $^{28}$

Meskipun para pengungsi telah dipulangkan, bukan berarti hubungan antara warga Syiah dan yang lainnya menjadi baik dan harmonis, ketegangan masih ada di antara mereka. Propaganda mengenai

25 Ibid. Alasan pengambilan keputusan penyesatan aliran Syiah dapat dilihat pada Keputusan Fatwa Majelis Ulama Indonesia (MUI) Provinsi Jawa Timur No. Kep01/SKF-MUI/JTM/I/2012 Tentang Kesesatan Ajaran Syiah. MUI Provinsi Jawa Timur pada sidang hari Sabtu, 21 Januari 2012, lampiran ke-3.

${ }^{26}$ KontraS, Laporan Investigasi dan Pemantauan Kasus Syi'ab Sampang, 15.

27 Muhammad Afdillah, Dari Masjid ke Panggung Politik: Studi Kasus Peran Pemuka Agama dan Politisi dalam Konflik Kekerasan Agama antara Komunitas Sunni dan Syiah di Sampang Jawa Timur (Tesis-Universitas Gadjah Mada, Yogyakarta, 2013), lampiran 1.

${ }^{28}$ Ibid. 
kesesatan Syiah dalam berbagai bentuk tetap tersebar di masyarakat. Hubungan antar tetangga semakin memburuk, setali tiga uang dengan hubungan antar kerabat. Masyarakat yang berbeda kelompok tidak lagi saling menyapa, kebersamaan dalam kegiatan masyarakat seperti: tasyakuran, mauludan dan kegiatan kemasyarakatan lainnya menghilang. Masyarakat enggan menerima pemberian dari kelompok lainnya bahkan, beredar anggapan bahwa, pemberian dari anggota kelompok lainnya adalah haram.

Kekerasan yang melibatkan kedua kelompok massa kembali pecah pada tanggal 26 Agustus 2012. Kekerasan bermula ketika massa bertengkar dengan Ummi Hani dan hendak menghadang anak-anak kelompok Syiah yang akan kembali ke pesantren masing-masing. Mobil yang dinaiki anak-anak Syiah kemudian kembali ke kediaman Tajul Muluk. Massa yang telah berkumpul mengepung rumah tersebut. Kekerasan pecah saat upaya salah satu warga Syiah bernegosiasi dengan penyerang gagal. Selain penyerangan terhadap warga Syiah, hal lain yang dilakukan massa adalah pembakaran rumah-rumah warga Syiah. Warga Syiah kemudian dievakuasi ke GOR Tennis Indoor. Satu orang warga Syiah tewas dan puluhan rumah warga Syiah terbakar pada kejadian itu. ${ }^{29}$

3. Periode Pasca konflik

Tanggal 26 Agustus 2012 malam, diadakan rapat koordinasi antar berbagai pihak membahas kekerasan yang baru saja terjadi. Pihak yang terlibat dalam pertemuan tersebut adalah Polda Jatim, Kepala Bakesbangpol Sampang, Kabag Humas Kanwil Kemenag (Kantor Wilayah Kementerian Agama) Provinsi Jatim, Kepala Kankemenag Sampang, serta tokoh agama dan tokoh masyarakat di sekitar daerah konflik. Rapat ini diadakan di Pesantren Darul Ulum, Gersempal, Omben, Kabupaten Sampang. ${ }^{30}$

Pada tanggal 3 September 2012, Ka Kankemenag Kabupaten Sampang membentuk Tim Penanganan Kasus Sampang Tahun 2012

${ }^{29}$ Kelompok Kerja Advokasi Kebebasan Beragama/Berkeyakinan (Pokja AKBB) Jatim, Kronologi Syawal Berdarah di Sampang (versi 28 Agustus).

${ }^{30}$ Rekam Jejak Penanganan (Track Record) Penanganan Sampang, 2. 
yang dipimpin oleh Abd. Hamid, Kepala Seksi Penerangan Masyarakat. ${ }^{31}$ Tim Penanganan Kasus Sampang ini ditunjuk berdasarkan Surat Keputusan no. Kd.13.27/6/BA.02/146/SK/2012. Tugas utama yang diembankan pada tim adalah merencanakan, melaksanakan, mengendalikan, dan mengoordinasikan kegiatan penanganan konflik Sampang.

Tim bergerak mulai tanggal 19 September melalui pengadaan pertemuan dengan K.H Abuya Ali Karrar Shinhaji di desa Lenteng, Kecamatan Propoh, Kabupaten Pamekasan. Pertemuan ini dilakukan guna mencari peluang memulangkan para pengungsi. Jawaban yang diterima dari Kiai Karrar adalah masyarakat setempat belum siap menerima kepulangan para pengungsi dan meminta sehingga pemulangan pun belum dapat dilaksanakan.

Sehari setelahnya, pada tanggal 20 September 2012 tim rekonsiliasi menemui pengurus ABI, Umar Shahab dan Ahmad Hidayat. Kunjungan ini dilakukan di Kantor Perwakilan ABI Jawa Timur di Jakarta, tepatnya di Jl. Pasuruan No.16, Menteng. Hasil yang disepakati dalam kunjungan ini adalah kesepakatan untuk menyatukan Tajul dan Rois, menghentikan media memojokkan masyarakat sekitar, dan membuka kembali usul relokasi pengungsi secara sukarela. ${ }^{32}$

Selanjutnya, pada tanggal 21 September 2012 tim menemui ketua IJABI, Jalaluddin Rahmat di Jakarta Selatan. Meskipun secara organisasi, Tajul sudah tidak termasuk dalam anggota IJABI tetapi, IJABI bersedia membantu. Bantuan yang diberikan berupa bantuan logistik dan mengusahakan koordinasi antara IJABI dan ABI untuk mengupayakan komunikasi Sunni-Syiah. ${ }^{33}$

Tanggal 26 September 2012, tim mengadakan serap aspirasi dengan mengumpulkan tokoh-tokoh yang dianggap terlibat dalam konflik. Tujuan dari serap aspirasi ini agar didapatkan pemecahan masalah yang tepat. Pertemuan ini dihadiri oleh sekitar 40 orang. Melalui serap aspirasi ini diketahui bahwa meskipun para tokoh dan masyarakat

\footnotetext{
${ }^{31}$ Samsul Anam, Wawancara, 29 April 2014.

32 Rekam Jejak Penanganan (Track Record) Penanganan Sampang, 2.

33 Afdillah, Dari Masjid ke Panggung Politik, lampiran 1.
} 
tidak menolak kepulangan pengungsi Syiah, mereka masih takut akan terjadi kekerasan seperti yang terjadi sebelumnya jika pengungsi diizinkan untuk kembali. Selain itu, masyarakat juga menuntut penegakan hukum baik terhadap pihak Sunni maupun pihak Syiah. Yang terakhir, masyarakat menginginkan agar hak-hak mereka diakui di rumah mereka (rumah fisik, rumah ideologis, rumah budaya, maupun historis) sama seperti sebelum Tajul menyebarkan ajarannya. ${ }^{34}$

Pada hari Jumat 5 Oktober 2012, tim melakukan pertemuan di kantor Kankemenag Sampang. Pertemuan dihadiri oleh ulama dari MUI, NU, dan BASSRA. Dari hasil pertemuan ini dibentuk Keputusan Bersama yang ditujukan kepada Bupati Kabupaten Sampang. Surat tersebut berisi ketidaksetujuan atas upaya pemulangan kelompok Syiah ke Sampang dan permintaan agar kelompok Syiah dikeluarkan dari pulau Madura. $^{35}$

Berbeda dengan kondisi masyarakat Syiah yang berada di pengungsian dengan berbagai permasalahannya, kondisi masyarakat Sunni sedikit lebih baik. Masyarakat yang berada di Dusun Nangkernang, Desa Karang Gayam, Kecamatan Omben dan Dusun Gadding Laok, Desa Blu'uran, Kecamatan Karang Penang menerima bantuan berupa uang tunai dari Kanwil Kementerian Agama Jawa Timur. Pembagian dana ini dilaksanakan pada 06 Oktober 2012. Sebanyak 150 KK menerima bantuan uang dengan nominal Rp. 250.000. Alasan pembagian uang ini adalah untuk menunjang ekonomi warga di wilayah konflik yang dianggap masih mengalami trauma sehingga aktivitas perekonomian tidak berjalan maksimal. ${ }^{36}$

Atas permintaan dari Kanwil Kemenag Provinsi Jawa Timur, tim rekonsiliasi Kankemenag Sampang mengirim 10 peserta dari Kabupaten Sampang pada acara Dialog Kerukunan yang diadakan oleh Pusat Kerukunan Umat Beragama (PKUB) Kementerian Agama RI. 10 orang tersebut berasal dari 2 orang NU, 2 orang MUI, 2 orang Syiah, 2 orang tokoh masyarakat, dan 2 orang dari Kemenag Sampang. Dialog ini

\footnotetext{
${ }^{34}$ Ibid.

35 Ibid.

${ }^{36} \mathrm{Ibid}$
} 
diadakan pada tanggal 15 hingga 19 Oktober 2012 di The Empire Palace, Surabaya. Perkembangan cukup baik sepulangnya utusan dari acara tersebut. Penganut Syiah mulai dapat membaur dengan yang lain, bahkan telah terjadi bantuan berupa tawaran pekerjaan dari kelompok Sunni. ${ }^{37}$

Pada tanggal 3-5 Desember 2012, Kantor Kementerian Agama Kabupaten Sampang bekerja sama dengan Puslitbang Kehidupan Keagamaan, Badan Litbang dan Diklat Kementerian Agama RI mengadakan sebuah workshop. Kegiatan ini mengambil nama "Prakarsa Perdamaian Berbasis Komunitas dan Kearifan Lokal Pasca-Konflik Horizontal di Kabupaten Sampang" diadakan di Arca Cottages \& Resort, Trawas, Mojokerto. Pihak yang hadir dalam pertemuan ini berjumlah 60 orang, yakni 10 Sunni, 10 Tokoh Masyarakat, 10 Tokoh Pemuda, 8 Syiah, 10 Aparat Keamanan, dan 12 orang Aparat Pemerintah. Acara yang dilakukan dalam forum ini selain workshop adalah kegiatan outbond dan silaturahmi ke pihak Sunni di Pondok Pesantren Al-Hikam, serta kunjungan ke Iran Corner di Universitas Muhammadiyah Malang. ${ }^{38}$

Tim rekonsiliasi Kankemenag Sampang kembali mengirim utusannya dalam acara workshop yang diselenggarakan oleh Pusat Kerukunan Umat Beragama, Sekretariat Jenderal Kementerian Agama RI. Kali ini acara tersebut mengambil tema "Prakarsa Perdamaian Berbasis Religiositas dan Kearifan Lokal Masyarakat Sampang". Workshop ini dilaksanakan pada tanggal 10 sampai 12 Desember 2012 di Sun City Hotel, Sidoarjo. Sebanyak 42 peserta hadir dari berbagai kalangan dengan perincian 10 Sunni, 10 Syiah, 10 tokoh masyarakat, 8 tokoh pemuda, dan 4 mewakili aparat pemerintah Kabupaten Sampang. Hasil dari workshop ini adalah kesepakatan bersama untuk bermusyawarah dalam menyikapi permasalahan yang terjadi. Kesepakatan lain adalah adanya jaminan keamanan bagi masing-masing pihak yang hendak bersilaturahmi. ${ }^{39}$

Tanggal 26-27 Desember 2012, Kantor Kementerian Agama Kabupaten Sampang bekerja sama dengan KontraS Surabaya

\footnotetext{
${ }^{37}$ Rekam Jejak Penanganan (Track Record) Penanganan Sampang, 5.

${ }^{38}$ Ibid.

${ }^{39} \mathrm{Ibid}$.
} 
mengadakan Forum Group Discussion (FGD).Kegiatan yang dilangsungkan di Hotel Fortuna, Surabaya ini mengambil tema "Prakarsa Perdamaian Berkelanjutan (The Sustainable Peace) Berbasis Kearifan Lokal Masyarakat Sampang”. Sejumlah 23 orang hadir dalam kegiatan ini, mereka berasal dari 8 orang Sunni, 6 tokoh masyarakat, 4 orang tokoh pemuda, dan 5 orang dari komunitas Syiah. FGD kali ini menghasilkan 4 kesepakatan untuk melupakan kejadian konflik, kesepakatan untuk saling mengunjungi, persiapan semua peserta untuk menjadi kader perdamaian, serta meminta pemerintah menyediakan forum lanjutan dan membangun kembali rumah para pengungsi. ${ }^{40}$

Selang sebulan, pada tanggal 20 Juni 2013, sejumlah massa mendatangi GOR Tennis Indoor Kabupaten Sampang. Mereka mendesak agar pemerintah memindahkan pengungsi Syiah ke Rusunawa Jemundo, Sidoarjo. Menanggapi tuntutan ini, Pemkab Sampang memindahkan pengungsi dengan 3 truk, 2 bus polisi, dan dikawal dengan 2 mobil polisi. Sejak saat itu, sekitar 168 orang pengungsi Syiah menempati Rusunawa Jemundo, Sidoarjo. ${ }^{41}$

Sekitar bulan Juli 2013, Pemerintah Provinsi Jawa Timur berinisiatif mengambil alih penyelesaian konflik dari Pemerintah Kabupaten Sampang. Langkah ini diambil setelah terjadi pengusiran paksa para pengungsi Syiah dari GOR Tennis Indoor Sampang. Para pengungsi dipindahkan ke Puspa Agro Jemundo Sidoarjo. ${ }^{42}$

\section{Telaah Civic Engagement dan Elite Integration}

Indikator utama keberadaan civic engagement adalah adanya interaksi timbal balik antara kedua pihak (kelompok). Interaksi yang dimaksudkan adalah pola interaksi bebas dan tidak terpengaruh oleh negara. Dalam masyarakat Sampang, interaksi ini dapat ditemukan pada masyarakat Sampang antar anggota dalam satu kelompok, dan tidak terwujud pada interaksi antar anggota dari kelompok yang berbeda.

\footnotetext{
40 Afdillah, Dari Masjid ke Panggung Politik, 126-127.

41 Laporan Tim Temuan dan Rekomendasi (TTR) tentang Penyerangan Terhadap Penganut Syiah di Sampang, 4.

42 Samsul Anam, Wawancara, 29 April 2014.
} 
Dengan demikian, pola engagement yang terwujud pada masyarakat yang berkonflik adalah intra-communal engagement.

Ciri dari intra-communal engagement adalah adanya interaksi yang baik antar anggota dalam suatu kelompok, dan kuatnya solidaritas di antara mereka. ${ }^{43}$ Pada masyarakat Sunni, interaksi antar anggota kelompok berjalan dengan baik, sama halnya dengan solidaritas mereka yang kuat. Hal ini dibuktikan melalui kesepakatan masyarakat yang menolak hadirnya Syiah di kampung halaman mereka. Masyarakat Sunni pun mengajukan syarat agar anggota kelompok Syiah bertobat jika ingin kembali ke kampung halaman.

Hal yang hampir sama ditemukan pada masyarakat Syiah. Kesolidan kelompok ini terlihat dari tuntutan mereka yang meminta dipulangkan secara serentak dan menolak pemulangan bertahap. Selain itu, kelompok Syiah pun bersedia menanggung kehidupan di penampungan bersama sesama anggota kelompok.

Berbeda dengan intra-communal engagement yang terlihat jelas, pola inter-communal engagement tidak terlihat dengan jelas. Pola hubungan antar kelompok menjadi begitu buruk setelah masyarakat terbagi dalam dua kelompok, Sunni dan Syiah. Pembagian masyarakat menjadi dua kelompok ini kemudian menciptakan garis pembatas antara kelompok Sunni dan Syiah.

Batasan tersebut membuat interaksi antar-kelompok semakin memburuk. Hal ini terlihat dari rasa saling curiga yang berkembang di masyarakat. Masing-masing kelompok bahkan tidak mau memakan makanan dari hajatan yang diselenggarakan oleh kelompok lain karena makanan tersebut dianggap haram. Beberapa orang yang menikah dengan anggota kelompok lain memutuskan untuk berpisah karena pernikahan itu dianggap tidak sah. ${ }^{44}$

Pembatas tersebut semakin menguat ketika masyarakat Syiah terusir dari Sampang. Interaksi sosial kedua kelompok menjadi hilang sama sekali. Jika ada interaksi dari kedua kelompok, interaksi tersebut

43 Varshney, Ethnic Conflict and Civic Life, 49.

${ }^{44}$ Iklil al-Milal, Wawancara, 10 Mei 2014. 
hanya bersifat artifisial. Pola ini tentu saja tidak dapat dikategorikan sebagai civic engagement.

Setelah kelompok Syiah berada di pengungsian, persepsi negatif atas mereka semakin berkembang di masyarakat Sunni. Ujaran kebencian dari para elit kemudian memperparah keadaan ini. Akibatnya, tidak ada lagi masyarakat Sunni yang menjenguk saudara mereka yang berada di pengungsian. Mereka takut dianggap sebagai pembela Syiah yang dianggap sesat.

Senada dengan civic engagement yang tidak terwujud, elite integration tidak terlihat pada interaksi kedua kelompok tersebut. Elit integration hanya terwujud hanya dalam kelompok Sunni. Integrasi ini melibatkan jaringan kiai di Madura. Untuk menjadi salah satu anggota dalam jaringan ini, seorang kiai harus memenuhi tiga syarat. Pertama, kiai tersebut berasal dari trah kiai. Memiliki pesantren (aktivitas pengajaran agama) yang berada di bawah pimpinannya adalah syarat kedua menjadi Kiai. Syarat terakhir seorang kiai haruslah anggota NU. Jika seorang kiai memenuhi ketiga syarat di atas, maka kiai tersebut otomatis masuk dalam jaringan ulama Madura. ${ }^{45}$

Elit dari kelompok Syiah memang memenuhi dua dari syarat yang diharuskan, namun tidak memenuhi syarat ketiga. Karena hal inilah kelompok kiai yang ada di Madura tidak mengakui elit dari kelompok Syiah sebagai seorang kiai. Disisi lain, meski tidak mendapat legitimasi sebagai seorang kiai, pemimpin kelompok Syiah tetap menjadi tokoh yang dianut dan ditaati oleh kelompok Syiah, sehingga dapat dikatakan sebagai elit. Sebab itu, elite integration antara kedua kelompok tetap harus dilaksanakan.

Ketidakadaan integrasi elit terlihat dari berbagai situasi yang terjadi selama konflik berlangsung. Berbagai keputusan yang diambil dalam pertemuan yang menghadirkan elit kelompok Syiah (Tajul) mewakili masalah ini. Dalam setiap kali pertemuan, Tajul diharuskan untuk menandatangani perjanjian untuk tidak menyebarkan ajaran yang ia yakini pada masyarakat. Bahkan, sering kali Tajul tidak diberi

45 Yanwar Pribadi, "Islam and Politics in Madura: Ulama and Other Local Leader in Search of Influence (1990-2010),” (Disertasi-Universiteit Leiden, 2013), 60. 
kesempatan untuk mengajukan pembelaannya. Jikalau diberi kesempatan untuk membela (menjelaskan ajarannya) elit kelompok lain pun tidak akan menerima apa yang ia sampaikan dan tetap meminta agar tidak menyebarkan ajaran Syiah.

Pertemuan-pertemuan yang kemudian digagas untuk mempertemukan kedua elit terkesan bersifat artifisial saja. Elit dari kedua kelompok yang dipertemukan bukanlah elit yang memiliki peran penting dalam proses konflik tersebut. ${ }^{46}$ Elit-elit yang menolak keberadaan kelompok Syiah, maupun elit yang ikut berperan dalam penyesatan Syiah belum dapat dipertemukan untuk melakukan dialog terbuka dengan elit kelompok Syiah.

Parahnya lagi, elit dari kedua kelompok ini memiliki massa masing-masing yang amat kuat dan solid mendukung elit mereka. Dampaknya, ketika para elit menolak untuk berdamai dengan elit dari kelompok lain, maka massa dari elit tersebut akan bersikap sesuai dengan sikap elit mereka.

Sikap yang ditunjukkan oleh massa dari elit tersebut merupakan bukti dari kuatnya hubungan patron-client yang ada pada masyarakat yang berkonflik. Pola patron-client ini menjadi salah satu faktor yang menyebabkan semakin besarnya disintegrasi. Hal ini disebabkan oleh banyaknya massa yang menjadi client dari para elit dan mengikuti sikap elit mereka, sehingga ketika elit mereka menolak keberadaan Syiah, massa dari masing-masing elit itu pun akan menolak keberadaan Syiah. Begitu pula dengan massa dari elit Syiah yang mengikuti sikap elit mereka untuk menolak pemulangan secara bertahap. Dari kedua sikap yang berbeda tersebut akhirnya memperluas jarak antara kelompok Syiah dan kelompok Sunni.

Untuk lebih mempermudah pemahaman mengenai posisi kedua kelompok dari Sunni dan Syiah, akan ditunjukkan sebuah skema. Skema ini menjelaskan berbagai bagaimana civic engagement dan elit integration berperan pada belum tuntasnya konflik antara kedua kelompok tersebut.

46 Ibid. 


\section{Gambar 2}
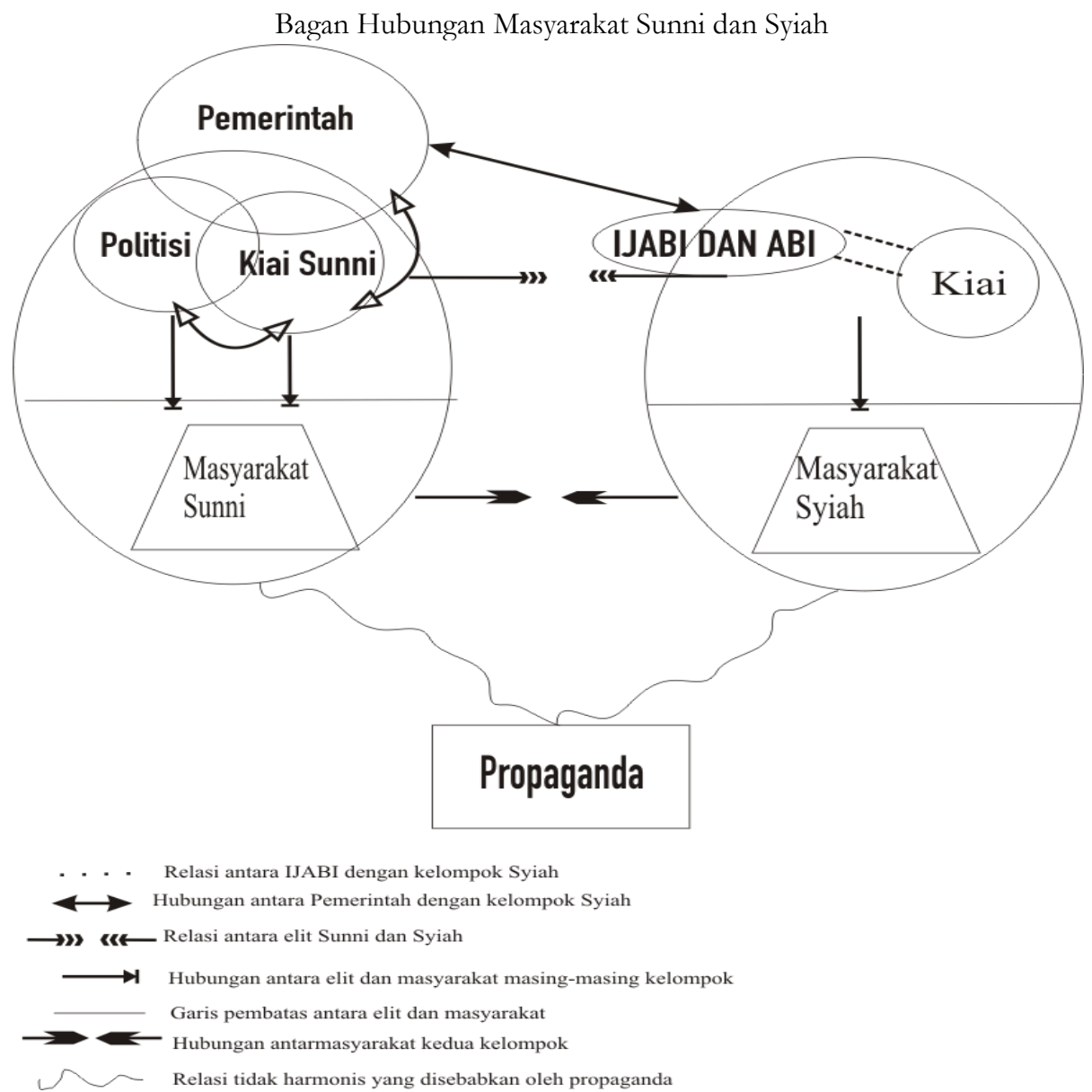

Gambar tersebut menunjukkan posisi dari beberapa pihak dalam konflik yang terjadi antara kelompok Sunni dan Syiah. Pihak-pihak yang terlibat memiliki relasi yang bervariasi. Variasi hubungan tersebut digambarkan melalui garis yang berbeda.

Garis yang paling atas adalah garis putus-putus yang menghubungkan IJABI dengan kelompok Syiah. Garis ini 
menggambarkan relasi IJABI dan kelompok Syiah yang pernah terhubung namun kemudian terputus. Melalui garis ini dapat digambarkan bahwa IJABI saat ini tidak memiliki peran secara struktural terhadap kelompok Syiah yang kini terafiliasi dengan ABI. Meskipun demikian, kelompok Syiah pimpinan Tajul Muluk ${ }^{47}$ juga pernah bernaung di bawah IJABI, dan kini peran IJABI hanya bersifat kemanusiaan dengan membantu logistik pengungsi Syiah. ${ }^{48}$

Hubungan yang lebih kompleks terjadi antara pemerintah dengan kelompok Syiah, khususnya dengan para elitnya. Kompleksitas ini diakibatkan oleh posisi pemerintah sendiri yang secara umum berada dalam kelompok Sunni. Hampir semua aparatur negara dan pimpinan Pemerintah Kabupaten Sampang mempunyai afiliasi dengan para kiai Sunni, baik dari segi politik, sosial, dan pendidikan. Posisi tersebut mengakibatkan dilema tersendiri bagi pemerintah. Di satu sisi, pemerintah diharapkan menjadi pihak netral dalam konflik tersebut, namun di sisi lain pemerintah tetap memiliki subjektifitas sebagai anggota dari kelompok Sunni. Hal ini dibuktikan dari beberapa keputusan mengenai penolakan adanya aliran Syiah dan pernyataan bahwa Syiah adalah sesat yang dikeluarkan oleh pemerintah.

Hubungan pemerintah dengan kelompok Syiah juga tidak harmonis. Hal ini digambarkan dengan garis yang memiliki arah panah berlawanan. Garis ini adalah simbol dari sikap yang saling menolak mengenai solusi yang hendak diambil. Pemerintah menginginkan kelompok Syiah bersedia direlokasi, namun kelompok Syiah sendiri menolak dan meminta agar dikembalikan ke kampung halamannya. Meskipun menghadapi penolakan dari kelompok Syiah, pada akhirnya pemerintah berhasil melakukan relokasi tersebut.

Relasi yang ada pada elit dalam kelompok Syiah pun memiliki pola yang tidak kuat. Saat ini, kelompok Syiah memang berafiliasi pada ABI, namun peran ABI pun tidak bisa dikatakan memiliki pengaruh yang signifikan terhadap kelompok Syiah. Untuk itu, simbol dari relasi antara

\footnotetext{
47 AMAN Indonesia, Dilema Kebebasan Beragama di Indonesia: Studi Kasus Pembakaran Rumah Ibadah di Sampang Madura (The Asian Muslim Action Network Indonesia, 2012), 21.

${ }^{48}$ Rekam Jejak Penanganan (Track Record) Penanganan Sampang, 5.
} 
ABI dan Kiai kelompok Syiah digambarkan melalui dua garis yang putusputus. Hal ini menunjukkan meskipun ABI dan Kiai Syiah memiliki hubungan timbal balik, namun relasi timbal balik mereka tidak kuat. Kelemahan hubungan ini terlihat dari peran ABI sendiri yang meski pun telah berdiskusi dengan berbagai pihak, namun belum dapat mengembalikan Syiah ke kampung halamannya. Koordinasi yang dilakukan dengan masyarakat Syiah Sampang pun terkesan minim. Memang, ABI berperan dalam membantu advokasi hukum Tajul Muluk dan beberapa pengikutnya, namun sentuhan ABI agaknya lebih tertuju pada koordinasi dengan elit dari berbagai pihak, tidak secara langsung bersentuhan pada kelompok yang dinaunginya (masyarakat Syiah Sampang).

Kelompok Sunni memiliki kelompok elit yang terintegrasi dengan baik. Seperti tergambar melalui garis kurva yang memiliki dua ujung panah tersebut. Masing-masing pihak dalam elit Sunni memiliki hubungan yang kuat dengan pihak lain. Relasi antara politisi, Kiai, dan pemerintah memiliki pola hubungan yang sama kuat. Hal lain yang memperkuat relasi ini adalah posisi elit Sunni sendiri, terdapat beberapa orang yang memiliki posisi baik sebagai politisi, Kiai, maupun pemerintah. Dengan demikian mereka dapat memperkuat dan mengelola relasi yang ada pada elit Sunni. Meski elit Sunni terdiri dari tiga unsur, namun yang terkuat adalah kelompok kiai. Warna abu-abu yang menyelimuti lingkaran kelompok Kiai menunjukkan bahwa kelompok inilah yang memiliki kekuasaan paling besar. Kiai mempengaruhi hampir semua kebijakan yang diambil oleh elit kelompok Sunni yang menolak pemulangan kembali kelompok Syiah. Legitimasi kekuasaan ini juga ditunjang oleh hierarki kepatuhan masyarakat Madura. Kiai memiliki posisi kedua sebagai sosok yang paling dihormati oleh masyarakat.

Relasi lain yang memiliki pola tolak-menolak adalah hubungan antara elit Sunni dan elit Syiah. Elit Sunni memiliki posisi yang lebih kuat karena selain terdiri dari pemuka agama Sunni juga terdiri dari pihak politisi dan pemerintah Kabupaten Sampang. Sedangkan posisi elit Syiah terdiri dari pemuka agama mereka yang juga anggota dari ABI. Relasi elit kedua kelompok ini sangat tidak harmonis dan bertolak belakang. Masing-masing elit berusaha untuk bertahan pada posisi yang mereka 
inginkan. Elit Sunni berusaha bertahan sebagai elit yang memegang peran dalam kehidupan masyarakat Sampang (the rulling class) dan berusaha menolak keberadaan elit Syiah yang dianggap akan merebut kekuasaan mereka. Sedangkan elit Syiah sendiri bersikeras bahwa keberadaan mereka merupakan hak dan tidak bisa diganggu gugat. Elit Syiah juga berpendapat bahwa keberadaan mereka adalah sebagai pembaharu tradisi yang dianggap memberatkan warga.

Elit dari kedua kelompok tersebut berusaha mempertahankan pengikut mereka masing-masing melalui relasi yang tergambar melalui panah vertikal dengan ujung tumpul. Anak panah satu arah ini memperlihatkan bahwa hubungan antara elit dengan masyarakatnya adalah relasi kepatuhan. Hal ini berarti masyarakat tidak memiliki keberanian menunjukkan ketidaksetujuan terhadap elit yang mereka anut. Apalagi elit agama merupakan salah satu tokoh dari hierarki kepatuhan yang dianut masyarakat Madura.

Garis horizontal yang berada di antara elit dan masyarakat menunjukkan pola hubungan patron-client pada masyarakat tersebut. Garis horizontal ini mempertegas hubungan yang digambarkan melalui panah vertikal sebelumnya. Dengan adanya pembatas tersebut, posisi elit semakin kuat dan menjadi penentu kebijakan kelompok mereka tanpa bisa diganggu oleh masyarakatnya.

Senada dengan hubungan antara elit Sunni dan Syiah, hubungan masyarakat kedua kelompok pun tidak harmonis. Hal ini dicerminkan melalui garis panah yang saling berhadapan. Penyebab dari relasi ini adalah hubungan yang tidak harmonis di kalangan elit mereka, sehingga masyarakat yang memiliki posisi sebagai client mengambil sikap yang sama dengan para elitnya.

Ketidakharmonisan ini diperparah dengan adanya propaganda yang menyebar di kalangan masyarakat. Berbagai propaganda ini kemudian memperkuat kecurigaan dan penolakan kedua kelompok. Hal ini yang kemudian bisa menyebabkan kekerasan yang terjadi berulangulang.

Satu lagi penyebab ketidakharmonisan kedua kelompok adalah adanya intra-communal engagement. Pola ini diwakili oleh bentuk elips yang 
menaungi beberapa unsur dari masing-masing kelompok. Pada kelompok Sunni, garis elips ini menaungi politisi, kiai, dan sebagian kecil pemerintah, serta masyarakat Sunni sendiri. Berbeda dengan kelompok Syiah yang hanya menaungi elit Syiah dan masyarakatnya.

Gambar tersebut menjelaskan bahwa dalam hubungan kedua kelompok masyarakat ini tidak terwujud inter-communal engagement dan elit integration. Sedangkan civic engagement hanya terwujud pada anggota dalam kelompok masing-masing, atau yang lebih tepat disebut sebagai intracommunal engagement.

Berdasarkan hal ini dapat dijelaskan bagaimana rekonsiliasi selama ini belum menemukan titik kesepakatan. Karena tidak adanya inter-communal engagement, maka antar anggota kelompok Syiah dan anggota kelompok Sunni tidak dapat berkomunikasi dengan baik dan mengambil keputusan sendiri untuk menyelesaikan permasalahan mereka. Elite integration juga tidak dapat terwujud karena masing-masing elite memiliki pendirian mereka sendiri yang dianggap sebagai harga mati dan tidak dapat ditawar.

\section{Penutup}

Civic engagement tidak dapat terwujud sepenuhnya pada masyarakat yang berkonflik. Hanya intra-communal engagement yang terwujud pada masyarakat. Inter-communal engagement tidak dapat terwujud sejak masyarakat terbagi menjadi dua kelompok, Sunni dan Syiah. Kuatnya intra-communal engagement dan lemahnya inter-communal engagement semakin memperparah konflik yang ada. Apalagi jika mengacu pada Varshney, intra-communal engagement dapat dikatakan sebagai salah satu penyebab terjadinya konflik. ${ }^{49}$ Kondisi ini membuat masyarakat semakin solid pada kelompok masing-masing dan tidak menerima usulan dari kelompok lain.

Elit integration tidak dapat terwujud antara elit dari kedua kelompok. Hal ini disebabkan tidak adanya legitimasi dari para kiai terhadap elit dari Syiah karena elit Syiah tidak memenuhi kriteria ketiga seorang kiai. Elite integration hanya terwujud pada elit dari kelompok

${ }^{49}$ Varshney, Ethnic Conflict and Civic Life, 12. 
Sunni. Ketiadaan elite integration ini menyebabkan disintegrasi semakin luas karena masing-masing elit memiliki massa yang bersikap sama dengan elitnya.

\section{Daftar Pustaka}

Afdillah, Muhammad. Dari Masjid ke Panggung Politik: Studi Kasus Peran Pemuka Agama dan Politisi dalam Konflik Kekerasan Agama antara Komunitas Sunni dan Syiah di Sampang Jawa Timur, Tesis tidak diterbitkan. Tesis-Universitas Gadjah Mada Yogyakarta, 2013.

AMAN Indonesia. Dilema Kebebasan Beragama di Indonesia: Studi Kasus Pembakaran Rumah Ibadah di Sampang Madura. The Asian Muslim Action Network Indonesia, 2012.

Hamdi, Ahmad Zainul. "Klaim Religious Authority dalam Konflik SunniSyi'I Sampang Madura". Dalam ISLAMICA Vol. 6, No.2, Maret 2012.

Horowitz, Donald. Ethnic Groups in Conflict. Berkeley: University of California Press, 1985.

Kelompok Kerja Advokasi Kebebasan Beragama/Berkeyakinan (Pokja AKBB) Jatim, Kronologi Syawal Berdarah di Sampang (versi 28 Agustus).

Pribadi, Yanwar. Islam and Politics in Madura: Ulama and Other Local Leader in Search of Influence 1990-2010. Disertasi-Universiteit Leiden, 2013.

Putnam, Robert D. Making Democracy Work: Civic Tradition in Modern Italy. New Jersey: Princeton University Press, 1992.

Rekam Jejak Penanganan (Track Record) Penanganan Sampang.

Semendawai, A.H. dkk. Laporan Tim Temuan dan Rekomendasi, Tentang Penyerangan Terbadap Penganut Syiah di Sampang Madura (laporan ini dikeluarkan oleh KPAI, KOMNAS HAM, KOMNAS Perempuan, dan LPSK) 
Tadjoeddin, Muhammad Zulfan. "Civil Society Engagement and Communal Violence: Reflections of Various Hypotheses in the Context of Indonesia". Dalam Politics Administration and Change, No. 42 Desember 2004.

Tim Penyusun. Laporan Investigasi dan Pemantauan Kasus Syi'ah Sampang. Surabaya: Kontras, 2012.

Laporan Tim Temuan dan Rekomendasi (TTR) tentang Penyerangan Terhadap Penganut Syiah di Sampang

Varshney, Ashutosh. Ethnic Conflict and Civic Life: Hindus and Muslims in India. Yale: Yale University Press, 2002. . "Ethnic Conflict and Civil Society". Journal World Politic, Vol. 53 No. 3 April 2001.

Wiyata, A. Latief. Carok: Konflik Kekerasan dan Harga Diri Orang Madura. Yogyakarta: LKiS, 2006. 